\title{
The Implementation of Quantum Teaching to Increase Students Activities and Learning Outcomes for Primary School
}

\author{
Rina Wahyuningrum, Muhari, Totok Suyanto \\ Universitas Negeri Surabaya \\ Surabaya, Indonesia \\ rinawahyuningrum84@gmail.com
}

\begin{abstract}
This study aims to improve students' activity and learning outcomes of the social science under the sub theme "the uniqueness of the area where I live" through the application of quantum teaching model assisted with audiovisual media in the $4^{\text {th }}$ grade students of SDN Ujung V, Surabaya. This is a Classroom Action Research conducted in three cycles. The obstacles were emerged during the learning activities, especially on the time management and in conditioning the classroom atmosphere when the study was started. Based on the results obtained from the data analysis, it can be concluded that quantum teaching model with audiovisual media is effective to improve students' activity and learning outcomes.
\end{abstract}

Keywords-Quantum teaching, activities student, learning outcomes.

\section{INTRODUCTION}

Education is an effort to understand and planned to realize the stage of learning and learning techniques so that students will be active in developing their ability and gain a strength faith, identity, personal organizing, intelligence, as well as the expertise to be independent and team work [1]. National Education is an important factor that has great contribution in building nation. According to [2], the function of national education is to realize the competence and build a good character quality and culture in improving the citizens' knowledge, intends to cultivate students' ability to be piety to God Almighty, noble, healthy in terms of physical and spiritual, active, creative, and become a democratic citizen. [3] In this thematic system, the related indicators will appear only in high class of the elementary school, it is IPS (Social Sciences). While the subtheme to be studied is "the uniqueness of the area where I live".

To solve these problems teachers should use varied learning models when preparing the lesson. By using the teacher models and learning media can help students get news, skills, ideas, assume and put forward existing ideas. One of the options that can play a good role in improving students' activity and learning outcomes is the application of quantum teaching model with audiovisual media.
Quantum Teaching model is a design that describes the style in launching the learning activities, through the alignment of art elements and planned achievements, regardless of the content of the lesson and make all the meaningful material in learning activities, every speech, ideas, joint activities, that can improve the situation, delivery, and learning plan [4] [2]. Quantum Teaching [5] is a vibrant learning activity that involves links, relationships, and variations that optimize the learning process. Quantum Teaching centers on the active interaction in the classroom that builds the learning context [3]. The result of research using quantum teaching model showed the increase in students' activity and learning outcome with very significant result. Quantum teaching that with assisted audio-visual media can improve students' learning outcomes because this learning model is in accordance with the students' cognitive development. Moreover, students can engage directly to pour ideas and thoughts so that the teaching material is easier to understood and remember.

The explanation above stimulate the researcher to make those problems as the research material for classical action research under the title "The implementation of audiovisual assisted quantum teaching model to increase students activities and outcomes on subthemes of "the uniqueness of my living place" in the fourth grade of SDN Ujung V/30 Surabaya [6]"

\section{METHOD}

This research uses a Classroom Action Research (CAR) design that is focus on solving any learning problem faced by the teacher, improving the quality and result and test new things for the development. A brief description of its implementation procedures as follows: preparation, implementation, monitoring, and reflection[7] [4]. Moreover, CAR consists of cycles as the standard procedure of this design. Concerning the methodology of this research, the CAR model of Kemmis and Taggart is used by researchers. That implemented in three cycles [8][10].

This research was conducted around April to May, 2018 and tested on 37 students of grade IV elementary school. The study was conducted in three cycles, consist of planning, action and observation, reflection and revision. At the planning 
stage the learning tools were prepared as the learning media. The action and observation are done during the teaching and learning process in 70 minutes for each cycle, at this stage the process of learning is observed in detail by recording all student activities, advantages, and disadvantages of using quantum teaching-learning model. Additionally, students' understanding of the subtheme is also tested by the provision of tests that will produce good learning outcomes. In other words, the assessment can be obtained from the results of observation and tests. While the reflection is done after the teaching and learning process is over with the reference of observation and students' learning outcomes. At the end of each cycle, there will be a revision to find out the advantages and disadvantages of the implementation that has been planned as a reference for the next cycle.

\section{RESULTS AND DISCUSSION}

Learning in the classroom is done to achieve the learning objectives and can be tested with an evaluation or test. If the purpose of learning can be achieved well, then the learning model is said to be effective.

The effectiveness of the quantum teaching model is observed based on students' learning outcomes. The learning results are the results obtained through an independent learning activity or teaching and learning activities.

Each cycle in this study begins with a planning stage where the researcher prepares all the learning tools that will be used in the teaching and learning process. In the first cycle, the learning tools include a syllabus, lesson plans, textbooks, instructional media, student activity sheets, and questions for evaluation. All prepared learning tools are then validated by expert validators who ultimately determine whether the learning device used is valid or not. The prepared tools of the cycle $\mathrm{I}$ is valid and can be used in learning using quantum teaching model.

The second stage in each cycle is the main stage of this study because at this stage the effectiveness of the quantum teaching model is tested. This stage is carried out for 70 minutes in each cycle. During this stage, activities and students' learning outcomes are observed. In the cycle I, the students' development can be seen in table 1 .

Table 1. Increased student activity cycle I

\begin{tabular}{|l|c|}
\hline Kinds of Activities & Observation Research \\
\hline Visual Activities & 3.01 \\
\hline Oral Activities & 2.32 \\
\hline Listening Activities & 3.03 \\
\hline Writing Activities & 3.06 \\
\hline Motor Activities & 2.97 \\
\hline Emotional Activities & 2.26 \\
\hline
\end{tabular}

Table 1 shows the students' activity during learning still needs to be improved. This shows that the first cycle of learning by using quantum teaching model can be implemented well, but still need to be improved by minimizing the existing shortcomings.

The effectiveness of the quantum teaching model is also reflected in students' learning outcomes. The cognitive aspect of the students' learning outcomes was obtained from the test after the learning was done. Students' learning outcomes in cycle I can be seen in table 2 .

Table 2. Students' Learning outcomes in cycle 1

\begin{tabular}{|l|l|l|}
\hline Aspect & $\begin{array}{l}\text { Class Classical } \\
\text { Completeness }\end{array}$ & Average \\
\hline Cognitive & $62.16 \%$ & 74.72 \\
\hline
\end{tabular}

Table 2 shows that most students have completed the material very well, but the classical mastery still needs improvement. Because the expected classical thoroughness is $\geq$ $80 \%$. This value can actually be further enhanced by better planning and implementation of learning.

The final stage in cycle $\mathrm{I}$ is the stage of reflection and revision. At this stage the researcher reflects the learning that has been done by considering two main points, the implementation of the lesson plans and student learning outcomes. And revise all the weaknesses and deficiency during learning in cycle I. The results of analysis in cycle I showed good results, but can still be improved. Therefore, the researcher decided to continue this research on cycle II.

In cycle II all stages in the first cycle are repeated again. The planning stage is passed by making learning device that can already be used in quantum teaching cycle II. In cycle II, the result of student activity during learning is shown in table 3.

Table 3. Increased student activity cycle II

\begin{tabular}{|l|c|}
\hline Kinds of Activities & Observation Results \\
\hline Visual Activities & 3.24 \\
\hline Oral Activities & 2.56 \\
\hline Listening Activities & 3.22 \\
\hline Writing Activities & 3.41 \\
\hline Motor Activities & 3.19 \\
\hline Emotional Activities & 2.82 \\
\hline
\end{tabular}

Table 3 shows that all student activities during learning can be accomplished with good and excellent categories. This shows that the second cycle of learning by using quantum teaching is improved more and can be done better than in cycle I.

In the second cycle, student learning results was remeasured. The results of student learning in cycle II can be seen in table 4. 
Table 4. Results of the learning cycle II

\begin{tabular}{|l|l|l|}
\hline Aspect & $\begin{array}{l}\text { Class Classical } \\
\text { Completeness }\end{array}$ & Average \\
\hline Cognitive & $78.37 \%$ & 75.40 \\
\hline
\end{tabular}

Table 4 shows that the classical completeness of the class has increased and is already $\geq 80 \%$. This indicates that the implementation of the maximum quantum teaching plan will improve students' learning outcomes.

In the reflection and revision stage, the researcher analyzes the students' excellent learning outcomes and decides to continue this research in cycle III to ensure that the students' learning result completion is due to the quantum teaching model performed and not because of other factors.

In the first stage of the cycle III, the learning devices are made by fixing the deficiencies in learning devices in the previous two cycles. In the second stage, the lesson plans can be done very well as illustrated in table 5 .

Table 5. Increased student activity cycle III

\begin{tabular}{|l|c|}
\hline Kinds of Activities & Observation Results \\
\hline Visual Activities & 3.79 \\
\hline Oral Activities & 3.00 \\
\hline Listening Activities & 3.69 \\
\hline Writing Activities & 3.47 \\
\hline Motor Activities & 3.26 \\
\hline Emotional Activities & 3.00 \\
\hline
\end{tabular}

Table 5 shows that all activities in the lesson plan in cycle III can be accomplished with the very good category. This proves that quantum teaching can be applied very well in elementary school level which is proven by the application of maximal learning model.

The learning results in the cognitive aspects were again observed. The students' learning outcomes in the third cycle are illustrated in Table 6.

Table 6 Learning cycle III results

\begin{tabular}{|l|l|l|}
\hline Aspect & $\begin{array}{l}\text { Class Classical } \\
\text { Completeness }\end{array}$ & Average \\
\hline Cognitive & $86.48 \%$ & 78.78 \\
\hline
\end{tabular}

Table 6 shows that the classical completeness of the class is very good. Therefore, the researcher decided to stop the research in cycle III because the students' learning outcomes have achieved the learning objectives, even exceeding the initial expectations of the early learning. In addition, the three learning cycles conducted using quantum teaching model showed that the factors that influence students' learning outcomes are quantum teaching model. It can be proven by the use of the same learning model but different submatrix. This shows that the improvement of students' learning outcomes is the result of the use of quantum teaching model in learning.

Overall, students' learning outcomes of the three cycles using quantum teaching are shown in picture 1 .

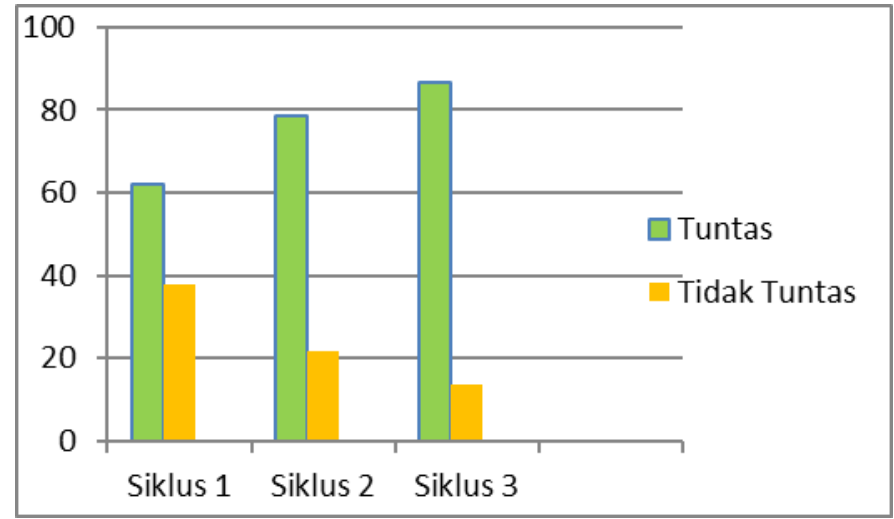

Picture 1. Results of student learning in three cycles Note: cycle 1 , cycle 2 , cycle 3

Tuntas $=$ successful

Tidak tunas $=$ not successful

Picture 1 shows a clear improvement in students' learning outcomes with a mastery over $75 \%$ on all cycles. These results indicate that learning using quantum teaching model is able to improve students' learning outcomes. The learning outcomes on the subtheme of "the uniqueness of the area where I live" also show the model is well suited to use in the material. This indicates that quantum teaching is an effective learning model used in elementary school level, especially on the "uniqueness area of my life" material.

\section{CONCLUSION}

The results showed the effectiveness of the use of quantum teaching model, especially on the subtheme of "the uniqueness of the area where I live”. The effectiveness of quantum teaching is evidenced by the increase of the students' activity and learning outcomes. Therefore, teachers are expected to apply the quantum teaching in their learning because it proves that is able to complete the learning objectives, because the selection of appropriate and effective learning model is important in improving the students' quality.

\section{SUGGESTION}

1. Based on research that has been done, quantum teaching model can increase students' activity, teachers' activity, and students' understanding, therefore the teacher should use quantum teaching model with audio-visual aid in social science learning with a similar condition [9].

2. Carrying out an interesting media is also one of the success factors. Teachers should use media that is very interesting so that students can focus on the delivered material.

\section{Acknowledgments}

Surabaya City Education Department as a scholarship provider of education. 


\section{References}

[1] I. A. No, "Year 2003 on National Education System," Jakarta Minist. Natl. Educ., 20AD.

[2] P. N. R. Indonesia, "Undang-Undang Republik Indonesia Nomor 43 Tahun 2007 Tentang Perpustakaan,” 2007.

[3] J. Jarkawi, "PROFESI GURU BIMBINGAN dan KONSELING DI ERA GLOBALISASI BERBASIS PENELITIAN," J. Bimbing. dan Konseling Ar-Rahman, vol. 1, no. 2, 2015.

[4] B. DePorter, M. Reardon, and S. Singer-Nourie, Quantum teaching: Orchestrating student success. Allyn and Bacon, 1999.
[5] Y. Riyanto, "Paradigma baru pembelajaran,” Jakarta: Kencana, 2010.

[6] Y. Rachmawati, "Strategi pendidikan anak Sekolah Dasar di wilayah Ekslokalisasi Surabaya: studi multi kasus di MI Unggulan Assa'adah Sememi-Benowo dan SD Baitu Ilmin Girilaya-Sawahan." UIN Sunan Ampel Surabaya, 2018.

[7] S. Arikunto and S. Suhardjono, "Penelitian tindakan kelas." Jakarta: Bumi Aksara, 2006.

[8] S. Jonathan, "Metode penelitian kuantitatif dan kualitatif." Graha Ilmu, 2006. 